\title{
Mobility, Empire and Cross-Cultural Contacts in Mongol Eurasia (MONGOL)
}

\author{
Michal Biran*
}

This essay reviews the ERC-funded project Mobility, Empire and Cross-Cultural Contacts in Mongol Eurasia conducted at the Hebrew University of Jerusalem (1/2013-12/2017). The project has studied the impact of the Mongol Empire (1206-1368) on world history through the prism of mobility. It aimed to explain why, how, when, and to where people ideas and artifacts moved across Eurasia and what were the outcomes of these population movements. Guided by »the humanistic approach to world history«, namely combining a world history perspective with a close reading of multilingual primary sources, the project has created a sophisticated prosopographical database for studying these movements. The database records multilingual information about people who were active in Mongol Eurasia, currently indexing more than 13,500 persons. This unique resource enables the study of various groups of migrants (tribes, captives, experts, etc.); networks of economic and cultural transfer; and various imperial institutions (army, diplomacy, imperial sons-in-law), thereby illuminating the era's social and cultural history. Stressing the pivotal role of the nomadic Mongols in initiating population movements, it analyses how these movements created multiple cross-cultural contacts; triggered massive ethnic, religious and geopolitical transformations, and led to a closer integration of the old world. The enhanced connectivity created both a common imperial culture - material, political, administrative - across Eurasia, and relativism of knowledge and religions. These, in turn, left a considerable imperial legacy to later polities, and helped shape the transition from the medieval to the early modern world. Yielding more than 80 publications so far, while various books, volumes and dissertations are in the making; training and grooming a considerable portion of the next generation of Mongol Empire scholars; and contributing significantly to the globalization of Mongolian studies worldwide, the project's main legacy has been the study of the Mongol Empire on its own terms and within its full Eurasian context.

Keywords: Mongol Empire; Mobility; Migration; Cross-Cultural Contacts; Digital Humanities; World History; Networks; China and the Muslim World; Islamization; Nomadic Culture.

* Correspondence details: Michal Biran, The Max and Sophie Mydans Foundation Professor in the Humanities, Institute of Asian and African Studies, The Hebrew University of Jerusalem, Mt. Scopus, 9190501, Israel; E-mail: biranm@mail.huji.ac.il; mongol.huji.ac.il. 


\section{Mobility, Empire and Cross-Cultural Contacts in Mongol Eurasia (MONGOL)}

The Mongol Empire (1206-1368) created a unique moment in world history: in the 13th and 14th centuries Chinggis Khan and his heirs founded and ruled the largest contiguous empire ever - an empire that at its height extended from Korea to Hungary, and from Iraq, Tibet, and Burma to Siberia. Moreover, ruling over roughly two thirds of the Old World and profoundly impacting regions beyond its reach, the Mongol Empire and its policies created remarkable mobility throughout Eurasia, with people, ideas, and artifacts traversing vast geographical and cultural expanses. This high degree of mobility constituted the first step towards robust cross-cultural exchanges in fields as varied as science, art, trade and religion, to name just a few. It triggered massive ethnic, religious and geopolitical transformations, led to a closer integration of the Old World, contributed to the discovery of the New World, left a considerable imperial legacy to later polities, and helped shape the transition from the medieval to the early modern world.

The study of this fascinating period and its impact on world history through the prism of mobility has been the crux of the ERC-funded project described below. ${ }^{1}$ Mobility - the ability of people, ideas, and artifacts to move or be moved across both space and society - has become a key concept in the study of contemporary history and the social sciences, ${ }^{2}$ yet it has been a forceful catalyst for major transformations in pre-modern periods as well, and the Mongol Empire is an outstanding example of its impact. Mobility saturated all levels of Mongolian life and history, from the Mongols' pastoral-nomadic economic adaptation, through their unprecedented military success, and up to the shaping of their imperial institutions. As a demographically marginal group, without experience in administrating sedentary territories, the Mongols were able to create and rule their vast empire only by fully mobilizing the resources - both human and material - that they extracted from the regions under their control. The rise of the empire, its continued expansion, and the establishment of its administration therefore involved a huge mobilization of people - followed by goods, techniques, institutions, texts and ideas - throughout the empire and further afield. This gigantic array of movements resulted in far reaching transformations, both intended and otherwise. As mentioned above, they created countless opportunities for cross-cultural transfer and enhanced identity changes such as the robust expansion of Islam and the considerable overhaul of the steppe people's ethnic makeup. Furthermore, the movements triggered significant demographic changes, swayed the politics, economy and culture of neighboring states, and expedited the spread of the Black Death across Eurasia. It blended imperial concepts of various origins (the Steppe, China, Islam), creating a set of functioning imperial institutions that bequeathed a different institutional legacy to each of the various civilizations that the Mongols encountered.

1 Consolidator grant n ${ }^{\circ} 312397$ under the European Union's Seventh Framework Programme (FP7/2007-2013).

2 On the »mobilities turn « in the social sciences see, e.g., Urry, Sociology Beyond Societies; Urry, Mobilities; Adey, Mobility; Cresswell, Mobilities I: Catching Up. 
Unprecedented human mobility was apparent chiefly in the period in which the empire existed as a unified, ever-expanding entity ruled from Mongolia (1206-1260), but continued on a smaller - but still quite significant - scale when the empire was eventually dissolved into four khanates or uluses, ${ }^{3}$ each of them a regional empire headed by a Chinggisid branch. The state headed by the Great Khan or Qa'an (in Mongolian Qa'an ulus) was centered in China and also ruled in Mongolia, Korea and Tibet. It became known as the Yuan dynasty (12711368) and enjoyed a nominal, though not uncontested, primacy over its counterparts. The Ilkhanate (1260-1335, in Mongolian Ulus Hülegü) was centered in modern Iran and Iraq, also ruling in Azerbaijan, Turkmenistan, parts of Anatolia and the Caucasus. The Golden Horde (1260-1502, Ulus Jochi) was centered in the Volga region, ruling from the eastern border of Hungary to Siberia, as well as in the Russian principalities. The Chaghadaid Khanate (12601678, Ulus Chaghadai) held power in Central Asia, from eastern Xinjiang (China) to Uzbekistan, up to Tamerlane's rise to power in 1370, and continued to rule in eastern Central Asia up to the late 1600 s. $^{4}$ Despite the many, and often bloody, disputes between the four polities, they retained a strong sense of Chinggisid unity. In the mid-14th century, all four khanates became embroiled in political crises that led to the collapse of the Ilkhanate and Yuan China, and considerably weakened the two steppe khanates. The fall of the Qa'an state in 1368 is generally deemed to be the end of the "Mongol Moment « in world history.

The project has aimed to assay mobility patterns under Mongol rule and the substantial changes it wrought. It is guided by two main questions: First: Why, how, when and to where did people, ideas and artifacts move in Mongol Eurasia? And second: What were the outcomes of these huge population movements?

More specifically, the project has focused on three interrelated themes: modes of migrations, the cultural and economic transfer; and the creation of a new imperial elite and institutions. Modes of migrations suggests a typology of migrations, along the full continuum between the coerced and the voluntary, and studies migrant groups and diasporas of various ethnicities, origins, destinations, professions and situations.

The cultural and economic transfer has been examined through a series of studies devoted to different professional groups in the Mongol Empire, such as astronomers, musicians, military experts and merchants, and highlights the religious, scientific and commercial networks within and beyond the empire's frontiers on the local, regional and continental level. This part has sought to explore the social context of bearers of such highly-prized skills in the Mongol world, examining their background, training, career patterns, patronage, relations with the Mongols, connections with other professional and social groups in their local communities (city) and beyond (khanate), and ties with their counterparts in other polities.

The third theme, Institutions and Elites, highlighting social mobility, has traced the development of the key imperial institutions (notably the imperial sons-in-law, with reference e.g., to the ruler's guard, the postal system, the juridical institutions, the diplomatic corps) through their personnel, either through a comparative perspective across Eurasia, or in specific parts of the Empire, thereby reassessing Mongol administration.

3 Ulus in Mongolian originally meant the people subject to a certain lord, and later also became an equivalent of a nation and state (the meaning it still has in modern Mongolian today).

4 The Mongol names of the three uluses derive from the names of their founders, two sons and a grandson of Chinggis Khan. 
Methodologically, the project has been grounded in sthe humanistic approach to world history «, ${ }^{5}$ namely, it combines a world history perspective with rigorous philological tools and close acquaintance with multilingual sources and different historiographical traditions (notably Chinese, Muslim - both Arabic and Persian - and Old Slavonic [medieval Russian]), thereby transcending the boundaries between different area studies. Simultaneously, it has been informed by insights from the social and life sciences - migration theory, network analysis, comparative study of empires and movement ecology. ${ }^{6}$

The project has benefitted from - and contributed to - the great deal of scholarly attention that has been devoted to the Mongol Empire over the past few decades. ${ }^{7}$ Notably, it has been inspired by the seminal works of Thomas T. Allsen. ${ }^{8}$ Familiar with sources in Chinese, Persian and Russian and fully aware of other languages and genres, Allsen looks at the empire from a holistic perspective, putting the Mongols and their nomadic culture at the center of his inquiry and highlighting the cultural exchange that took place under their rule. He has convincingly demonstrated that the Mongol Empire was not merely a passive medium that, by virtue of its expansive size and the relative Pax Mongolica, provided a propitious setting for trade and cultural interaction. Instead, the Mongols were the principal agents that advanced, cultivated, and directed such contacts and served as a filter that determined which particular cultural elements would be disseminated across the steppe and beyond. Allsen has also highlighted the importance of mobilization of resources and population movements for the Mongol Empire's development. His work has been the point of departure for the present project.

Practically, the project has been firmly based on close readings of a wide assortment of primary sources in multifarious languages, genres and disciplines. The information was classified into a sophisticated prosopographical database, which the project has developed for studying the population movements. The database, one of the project's major achievements, aims at recording the surviving information about individuals who were active under Mongol rule in the 13th and 14th centuries. Currently we have indexed more than 13,500 persons and are still counting.

The unique multilingual fully-relational database (JPP-SPRING) was originally built over the infrastructure of the Jerusalem Prosopographical Project (JPP) initiated by Prof. Michael Lecker of the Hebrew University for studying early Islamic history. Throughout the project's years it has been updated, modified, and considerably extended according to the project's needs by our programmers, notably Alon Klein-Orbach and later Itay Zandbank. The resulting internet-based database is conducive to a highly-nuanced classification of people and reports, notably by its ability to assign keywords of various levels to each report and person.

5 Subrahmanyam, Connected Histories.

6 E.g., Nathan, Movement Ecology; Hoerder, Cultures in Contact; Lucassen and Lucassen, Migration, Migration History, History; Lucassen, Lucassen and Manning, Migration History; Harzig et al., What is Migration History; Hollifield and Brettell, Migration Theory.

7 See Biran, State of the Field; Morgan, Mongol Historiography; and, e.g., Pederson et al., Pluvials, Droughts and the Mongol Empire; Aigle, Mongol Empire; McCausland, Mongol Century; De Nicola and Melville, Mongols' Middle East; Jackson, Mongols and Islamic World; Broadbridge, Women and the Making of the Mongol Empire; May, Mongol Empire; May and Jackson, Mongol and Post-Mongol Asia; Golden et al., Festschrift for Thomas T. Allsen; Pfeiffer, Tabriz; Amitai and Biran, Nomads as Agents of Cultural Change.

8 Esp. Allsen, Culture and Conquest; Allsen, Commodity and Exchange; Allsen, Population Movements. 
It enables the researchers to index the connections among various people, places, tribes, periods and activities; to make complicated searches, and to reconstruct the networks that were active across the empire and beyond its frontiers. There is a certain possibility to visualize the search results on maps and SNA graphs, as well as to export the data to specific software packages (e.g. Gephi) that specialize in producing more sophisticated visualizations.

The key building blocks of the database have been the rich biographical literature of Yuan China, Ilkhanid Iran and Mamluk Egypt (in Chinese, Persian and Arabic), while the rest of this edifice is comprised of a panoply of genres, such as multilingual chronicles; geographical works, travelogues, and guides for pilgrims; local histories and gazetteers; hagiographies; genealogies, as well as religious, literary and scientific works. The literary sources have been supplemented by multilingual documents and tomb inscriptions, and while archaeological, numismatic and visual resources are not yet an integral part of our database, they have been widely used in the specific sub-projects.

Material was uploaded to the database in two ways: systematic uploading of works, and sub-project uploading. Systematic uploading was based on a list of texts which I defined, beginning with the biographical sections of The official history of the Yuan dynasty, and the parts dealing with Mongolian history in Rashid al-Din's Compendium of Chronicles (in Thackston's translation) and Juwayni's History of World Conqueror (in Boyle's translation), as well as The Secret History of the Mongols (in De Rachewiltz's translation). Relevant information has been culled out, translated into English, when necessary, and has become a report, which has been subsequently linked to relevant people, places, tribes, periods and keywords. Scholarly translations, indices, and searchable databases (e.g. the Academia Sinica's 24 histories database or al-maktaba al-shamila) were used whenever available. Whenever electronic text was available, the original text was pasted at the end of the translated or summarized report.

In addition to the systematic uploading, each team member can upload material specifically relevant for his/her own sub-project into his/her private drawer of the database. It is mostly at this stage that more specific sources, including scientific, religious and literary works, some of which are still in manuscript, were consulted.

Texts were chosen according to their relevance and their degree of readability, and while we started with translated texts, many sources have been translated for the first time in the database. Most importantly, we translated and indexed a significant portion of the biographies of the Yuanshi, the official history of the Yuan dynasty (in Chinese), including all the biographies of the non-Han people, most of which had never been translated before. Furthermore, we located and translated a considerable number of Arabic biographies related to the Mongols or Mongol-ruled territories. While some of the Arabic material originated in the Mongol realm (notably in Iraq but also in Central Asia), most of it was written under the Mamluk Sultanate, which governed Egypt and Syria (1250-1517) in tandem with the Mongols. This Arabic material is one of the largest untapped reservoirs of sources for the study of the Mongol Empire. It is especially relevant to the history of the Ilkhanate and the Golden Horde, but also pertinent for the study of the other Mongol polities. ${ }^{9}$ 
The database therefore not only enables each researcher to index his/her information but also to use materials outside his/her linguistic proficiency (e.g. someone working on Muslim merchants can use the database for obtaining information on Chinese and European merchants, thereby enabling him to make comparisons or broaden his/her perspective; someone working on Persian materials can enrich his/her research by using the database's Arabic materials, etc.). It is also extremely helpful for identifying persons encountered in text from the 13th-14th centuries, mainly in the Muslim world, as well as serving as a good starting point for studying nearly any aspect of Mongol Eurasia: my study on captives in Mongol Eurasia, ${ }^{10}$ for example, began by searching for the keyword "captive" and checking the 259 relevant reports the database then held. While many of them contained merely generic statements (e.g. many captives were taken during the battle), others revealed the personal stories of those who were taken captive, took captives or redeemed captives, thereby suggesting an outline for the article. Currently the database is available for project members only, though limited guest access is available upon request. When the project's dissertations and books, which are based on the database, are completed, namely in about two years' time, we hope to make it open access.

The main novelty of this project has been its scale: it looks at the Mongol Empire from a holistic perspective, in its full Eurasian context. This perspective enables it to compare developments on an unprecedented scale and to stress the role of the Mongols and their indigenous culture in shaping the late medieval world.

The project is also unique due to its direct access to sources in Persian, Chinese, Arabic and Old Slavonic and its full awareness and use of sources in other languages, as well as by its use of advanced computer technology. This combination has allowed the project to move between micro, meso and macro history, moving from one individual or one family through the specific treatment of a certain professional group, city, tribe, diaspora, institution and up to continent-wide developments.

\section{Achievements:}

Apart from the database described above, in terms of publications, by its formal ending (December 2017) the project had yielded more than 80 publications - published, in press and accepted - while quite a few additional products (books, volumes, dissertations, articles) are in different stages of preparation. These publications indeed reflect the full spectrum of micro, meso and macro history.

On the micro level, I would like to point out two biographical collections, one already published and the other in an advanced stage of preparation. The first, titled: In the Service of the Khans: Elites in Transition in Mongol Eurasia, a special section of Asiatische Studien 71/4 (December 2017), 1051-1245, includes eleven articles - an introduction and ten annotated biographies, each prepared by a project member. The Mongol Empire generated massive transformations in the composition and functioning of elites across Eurasia as the new rulers adapted to ruling an enormous empire with a considerable sedentary realm, while employing huge numbers of their subjects in the imperial armies, courts and administrations, often in places far away from the latter's original homes. The articles included in this volume portray 
a multifaceted picture of the empire's new and multi-ethnic elite - from princes through generals, administrators, and vassal kings, to scientists and artists; including Mongols, Koreans, Chinese and Muslims. Moreover, it highlights the criteria for social mobility, such as early surrender to Chinggis Khan; noble birth (i.e. being related to the families of Chinggis Khan, contemporary or pre-Mongol ruling houses, or the Prophet Muhammad); membership in the Mongol guard (keshig); and, especially, merits, such as excellence in warfare, administration, literacy in Mongolian script or astronomy, to name just a few. The articles also illuminate bigger issues such as acculturation (of both the Mongols and their subjects), Islamization, family relations, ethnicity, imperial administration, and scientific exchange, as well as historiographical questions. The volume's title refers to In the Service of the Khan, published by Igor de Rachewiltz et al. ${ }^{11}$ but while the original book dealt with some of the main actors of the Mongol imperial enterprise, our volume focuses on second or third-tier elites, most of them hitherto not widely discussed (if at all) in the research literature. These assembled annotated biographies not only add new primary sources - translated from Chinese, Persian and Arabic - to the study of the Mongol Empire, but also provide us with important insights into the social history of a period unique in its rapid transformations.

The second biographical collection, which I edited together with two former project members Dr. Jonathan Brack and Dr. Francesca Fiaschetti, and which has just been submitted to California University Press, is titled Along the Silk Roads in Mongol Eurasia: Generals, Merchants, Intellectuals. Addressed to both scholars and students but catering specifically for classroom needs, the volume illustrates life along the Silk Roads by focusing on the individual stories of members of three, sometimes overlapping, elite groups - military commanders, merchants, and intellectuals - both male and female - from across Eurasia. The individuals featured in the volume again came from diverse backgrounds and ethnic compositions. They include Mongols, Chinese, Muslims, Qipchaqs and Europeans. Their personal experiences elucidate aspects of Eurasian cross-cultural contacts and physical and social mobility, from the formative years of Chinggis Khan (r. 1206-27) until the empire's collapse during the second half of the 14th century. It evinces some of the types of migrations characteristic of Mongol Eurasia (e.g., temporary and permanent relocation; coerced, impelled and voluntary migration; individual and collective mobility; as well as refugees, labour and student migrations); illustrates the scale, diversity, and creativity of the cultural and economic exchange along the Mongol Silk Roads, and offers a compelling starting point for any discussion of the Mongol Empire's impact on China, the Muslim world, and the West.

Most of the project's publications can be classified as dealing with meso-history, namely located between the micro and the macro, while tackling issues relevant to the project's themes, such as migrations - of tribes, ${ }^{12}$ ethnicities, ${ }^{13}$ merchants,,${ }^{14}$ astronomers, ${ }^{15}$ musicians ${ }^{16}$ and captives ${ }^{17}$ in various contexts; imperial institutions, such as Mongol diplomacy, ${ }^{18}$ schetti, Konzept des Auslandes; Grinberg, Foreign Policies of Janibeg. 
law, ${ }^{19}$ tax exemption ${ }^{20}$ and imperial sons-in-law; ${ }^{21}$ as well as migration of knowledge - both scientific and religious, with a special focus on astronomy ${ }^{22}$ on the one hand, and Islamiza$\operatorname{tion}^{23}$ on the other, but with reference also to "comparative religions ", namely presenting various religious traditions to different audiences - Mongols, Muslims or Chinese - ${ }^{24}$ as well as to mutual perceptions of Islam and Muslims in China and of China in Iran. ${ }^{25}$

My own work, apart from the items mentioned above and the macro-projects described below, has focused on several inter-related topics, namely Mongol and pre-Mongol Central Asia, in which emigration was a major phenomenon; ${ }^{26}$ historiography $;{ }^{27}$ and the cultural history of Ilkhanid Baghdad. ${ }^{28}$ This last theme is also the subject of a future book, in which the city will serve as a microcosmos for analyzing the project's themes of migrations, cross-cultural contacts and imperial institutions. Baghdad's alleged destruction and revival will also be tackled, and its fate under Mongol rule will be compared to that of Hangzhou, the capital of Song China, under the Yuan government.

In the meso category, I would also like to highlight another soon-to-be published special issue, as well as several research projects (three $\mathrm{PhD}$ theses and two book volumes) prepared by project members.

Mobility and Transformation: Cultural Exchange in Mongol Eurasia, will appear in the Journal of the Economic and Social History of the Orient issue 62/2-3 (2019). The volume consists of an introduction and seven studies (by Michal Biran, Sheila Blair, Peter Jackson, Kim Hodong, David Robinson, Qiao Yang and Yokkaichi Yashuhiru), most of which were first presented at the project's first big conference in 2014 (A Joint Research Conference of the Institute for Advanced Studies and the Israel Science Foundation, titled Mobility and Transformations: New Directions in the Study of the Mongol Empire). Whether they encompass most of the continent in a comparative perspective (Kim, Blair, Jackson, Yang) or focus on its eastern (Robinson) or western (Biran, Yokkaichi) corners, they all share a holistic outlook of the empire, and highlight the impact of the Mongols' indigenous norms on the proto-global world of the 13th and 14th centuries.

19 Hodous, Clash or Compromise; Hodous, Faith and the Law.

20 Cho, Negotiated Privilege.

21 Landa, From Mongolia to Khwarazm; Landa, Oirats in the Ilkhanate; Landa, Eurasian Migration.

22 Isahaya, Tärïkh-i Qitā; Yang, Like Stars in the Sky; Isahaya and Yang, Islamicate Astral Studies.

23 Biran, Islamization of Hülegü; Landa, New Light; Shurany, Islam in Northwest China; Amir, Sufis and Mamluks.

24 Brack, Mediating Sacred Kingship; Brack, Theologies of Auspicious Kingship; Brack, Mongol Mahdi.

25 Isahaya, Sino-Iranica; Isahaya and Mitsuaki, Persian Transcription; Qiu, The Mongol Empire in Sa dỉ’s Poems; Qiu, Independent Ruler, Indefinable Role; Qiu, A Coup d'état.

26 Biran, Mental Maps; Biran, Mamluks and Mongol Central Asia; Biran, Scholarship and Science; Biran, Liao Dynasty's Relations with the Muslim World; Biran, Qarakhanid Eastern Trade.

27 Amitai and Biran, Arabic Sources; Biran, Non-Han Dynasties.

28 Biran, Music in the Conquest of Baghdad; Biran, Violence and non-Violent; Biran, The Fall and Rise; Biran, Baghdad under Ilkhanid Rule; Biran, Libraries, Books and Transmission of Knowledge. 
As for the dissertations that the project members are currently working on, all of them (namely the three presented here and the two in the macro section) began with prosopographic studies but developed into bigger questions. Vered Shurany tackles the Yuan army, trying to answer a simple but highly significant question: How did the Mongol army manage to unite China in the 1270s, a task that earlier nomads had never accomplished, and why, less than a century later, was this once formidable army unable to deal with Chinese rebellions and escaped back to Mongolia? Despite the obvious importance of the army to Yuan history, the issue has not being widely studied in either western or Chinese scholarship, partly due to the complex and piecemeal composition of this army. Shurany's project begins by analyzing the biographies of Yuan generals in the Yuan official history (and other sources) and then moves on to identify various components (e.g. princes, guards, navy) and institutions of the Yuan military machine, as well as their transformation throughout Yuan rule.

Matanya Gill's dissertation deals with Ilkhanid trade, highlighting the role of the ortaqs - merchants operating with the capital of a Mongol prince or courtier - in the complex commercial system that centered in Iran. Based on analysis of more than 250 biographies of merchants as well as the use of theories of pre-modern economic history, his work illuminates the global trade networks that the Mongols created, which covered the whole old world.

Or Amir's work belongs to the project's "Mamluk wing " ${ }^{29}$ which focuses on the study of the Mamluk Sultanate. Studying the relations between the Mamluks and their Sufi sheikhs, Amir analyses narrative, epigraphic and material sources, combining them with social sciences perspectives on holy men and cultural capital, to shed new light on social life in areas which hitherto received little attention in scholarship. He stresses the vast patronage Mamluk officers gave to Sufi shaykhs, which facilitated the further expansion and popularization of Sufism, and greatly affected the formation of vernacular Islam in the Mamluk peripheries such as Greater Syria.

As for the project's core post-doctoral fellows, Francesca Fiaschetti, who finished her PhD during the project ${ }^{30}$ and is now turning it into an English book, explores aspects of Yuan diplomacy, military policy and ethnicity, with a special focus on the Yuan activity in south-east Asia. An important part of her work includes annotated translations of Chinese works, mainly the Yuanshi chapters on foreign countries (chapters 208-210), and the section on punitive expeditions in the Jingshi dadian (»Compendium for Ruling the World»), a 1330s mirror for princes (Yuanwenlei chapter 41). The research of Dr. Jonathan Brack, currently a Buber fellow in Jerusalem, examines cross-cultural contacts and exchanges across Asia and Iran, with a focus on the transmission of discourses on authority, sacral kingship and the afterlife during the period of Mongol rule and the early modern era. He is currently working on his first book manuscript titled An Afterlife for the Khan: Chinggis Khan's Heaven and the Eurasian Cultures of Disputation, which explores the lively inter-faith debates and intellectual inquiries at the Mongol courts in late medieval Iran within the broader narrative of inter-cultural

29 See e.g. Amir, Religious Lives; Amir, Local Elite; Mazor, Rise and Fall; Mazor, Early Experience; Mazor, Topos of Predicting the Future.

30 Fiaschetti, Konzept des Auslandes. 
polemical encounters and exchanges across Mongol Eurasia. Through the rich polemical works of the Jewish convert to Islam and Persian vizier, physician and historian, Rashid alDin (d. 1318), Brack examines how the inter-confessional encounters at the Mongol court, especially between representatives of the Sunnī and Shīi Muslim, Buddhist and Inner Asian religious traditions, led to experimenting with a new synthesis of sacral Muslim-Mongol kingship, extending his inquiry into the multi-confessional Mughal India (1526-1857).

Lastly, in the macro apart, I would like to introduce two other dissertations by project members, as well as my own forthcoming work. Ishayahu Landa's $\mathrm{PhD}$ project, submitted in early November 2018, deals with Imperial Sons-in-Law (güregen) in Mongol Eurasia, namely it tackles the highly selective and prestigious group of men who married into the Chinggisid family. They belonged to two groups: (a) military leaders who retained a certain segment of their tribal army and (b) vassal rulers (and in a few later cases also neighboring rulers). The tribal leaders were by far the more important group, and some lineages cemented multi-generational matrimonial alliances with the Golden Lineage from the days of Chinggis Khan up to the mid-late 14th century. Painstakingly following this unique group throughout the 13th and 14th centuries and in all the Mongol successor states, and based on sources in mainly Chinese, Persian, Arabic and Russian, Landa's work illuminates a unique segment of the Mongol elite, which in many cases eventually succeeded the Chinggisids. The study transforms our understanding of the organization of the Mongol army and highlights the uneasy balance between the commitment to Chinggis Khan's original policies and the practical needs of various rulers and uluses throughout the imperial span, as well as the shifts in nomadic identities under Mongol rules.

Yang Qiao's dissertation Patronage, Politics and Astral Sciences in Mongol Eurasia examines the interplay between the Mongol Empire and the astral sciences. The two questions leading the research are: How did the experts in astral sciences interact with each other and with the rulers in the Mongol Empire? How did the interaction shape the development of the astral sciences in the Mongol era? To answer them, she examines these interactions within the framework of the Mongol imperial mechanism of expert recruitment, the patronage networks, and bureaucratic, religious and educational institutions of the astral sciences, as well as critically reviewing the cross-cultural encounter of astral knowledge in a comparative approach, focusing primarily but not exclusively on Yuan China and Ilkhanid Iran. Shedding light on the interplay between empires and knowledge, and embedding the transmitted and received astral knowledge in its full social and cultural context, this work will significantly enhance our understanding of cross-cultural mechanisms in the different edges of Mongol Eurasia.

My own macro work includes, in addition to several general reviews of the empire's various aspects, ${ }^{31}$ one future book and two international enterprises. The book, under contract with Bloomsbury, titled The Mongol Empire: Mobility and Transformation in the Pre-Modern World, summarizes the project's insights. The core of the volumes analyzes specific aspects of mobility - of peoples (migrations), artifacts (economic globalization) and ideas (in the fields of science, art and cuisine; religions; collective identities; and political culture).

31 Biran, Mongol Empire and Inter-Civilizational Exchange; Biran, State of the Field, Biran, Mongol Imperial Space. 
It highlights the multi-faceted character of cross-cultural contacts in Mongol Eurasia: not only were more elements involved in these contacts but often the interaction among them (e.g. between European and Chinese, Muslims and Chinese or even Christians and Jews) was mediated through Mongol concepts, thereby creating a multi-cultural negotiation. These cross-cultural contacts generated a quantum leap forward in knowledge - geographical, linguistic, commercial, scientific, artistic and otherwise - as well as greater Eurasian connectivity, caused first by the empire's expansion but continued and intensified by the extensive commercial, religious and scholarly networks that the Mongols promoted or facilitated. This connectivity, and the huge population movements that set the stage for it, resulted in two complementary phenomena. First, the creation of a common culture - material, political, administrative - across Eurasia, though with obvious regional variants, from which future empires later adopted various elements; and second, relativism of knowledge and religion, promoted by the Mongols' multi-cultural outlook, which favored the amalgamation of legitimation concepts, celestial insurance and second opinions. Such connectivity and relativism can result in various forms of exchange, including diffusion, syncretism, conversion, crosspollination, acculturation, competition, conflict, or none of the above. Yet they certainly broadened the intellectual horizons of the Mongols, their subjects and neighbors, and modified the existing modes of thinking across Eurasia. Moreover, such relativism and commonalities, combined with the long-distance commercial and financial exchanges including the growing role of maritime trade; the formation of new collectivities due to ethnic and religious changes; as well as the notion of universal empire headed by sacred kingship, were all instrumental in ushering in the transition from the medieval to the early modern world. Based on close readings in a wide variety of primary sources from both the East and the West, and a sophisticated synthesis of the burgeoning secondary literature on the Mongols, the volume offers a fresh, analytical perspective on this transformative period in world history.

Closely connected to the ERC project are two other "macro" enterprises, The Cambridge History of the Mongol Empire and Comparative Study of Empires. The Cambridge History, which I edit together with Kim Hodong of Seoul National University, again departs from the same rationale that guided the project, namely looking at the empire from a holistic perspective and in its full Eurasian context, as well as in its own terms, not only as a chapter in the history of China, Iran, Russia or Central Asia. This gigantic international enterprise includes two volumes, one thematic and the other devoted to sources. The first one includes the political history of the empire and its main successor states; thematic histories, which tackle issues such as institutions, the economy, religions, art, science, gender, ethnicity and the environment; regional histories of specific realms inside the empire (Mongolia, Rus, Siberia, the Caucasus); as well as external histories which discuss the empire's impact beyond its realm, on Europe, South Asia, Maritime Asia and the Arab Middle East. The second volume is devoted to sources for the study of the empire. The lion's share deals with literary sources, divided according to (17!) languages, while special chapters are dedicated to archaeological and visual sources. Both volumes have been prepared by an international team of scholars from Europe, North America and Asia, and certain chapters paired two (or more) authors to combine expertize in different edges of the empire. This challenging enterprise is due to be submitted to Cambridge University Press in early 2019.

The second macro project, funded by the Humboldt Foundation via my Anneliese Maier Research Award, deals with the comparative study of empires. Pursued together with Prof. Yuri Pines (HUJI), Prof. Dr. Eva Cancik-Kirschbaum (Freie Universität Berlin), and Prof. Dr. Jörg Rüpke (Erfurt University), experts on the Chinese, the Assyrian and the Roman empires 
respectively, and dedicated to the memory of the eminent sociologist Shmuel Noah Eisenstadt (1923-2010), the project aims to offer a more systematic approach to empires than has been available to date. We have tried to single out common problems faced by imperial political structures worldwide and investigate how different empires in various parts of the world and in distinct periods of imperial formation tackled those problems. We cover intensively the five major civilization centers of the Old World (Near East, India, China, Inner Asia and Europe), the imperial formations in which developed through a certain degree of interaction and mutual fertilization. Whenever possible we add comparisons with imperial or quasi-imperial polities elsewhere (the Americas, Sub-Saharan Africa, and, of course, maritime empires), treating Eurasian empires roughly from the first millennium BCE to 1900 CE. The Mongol Empire, which brought together elements of various imperial traditions (Steppe, Chinese, Muslim) while its resulting complex imperial culture affected future empires across Eurasia - from Muscovy, the Ottomans, and Mamluks via the Safavids, Moghuls, and Uzbeks and up to Ming and Qing China - calls for such a longue durée comparative perspective that in itself highlights its diachronic uniqueness. The project is based on a series of topical workshops in which scholars working on different types of empires interact and explore a common set of questions. The first meeting, which took place in Erfurt on July 2015, was titled All under Heaven? The Empire's Spatial Dimensions. It analyzed both practical and ideological factors that prompted or limited the empires' expansion as well as the various forms of administration and representations of the imperial space. The second workshop, dealing with Empires and Religions, took place at the Freie Universität, Berlin on March 1-3, 2018, and discussed concrete examples for the ways in which empires and religions interact, how they inter-depend, and to what extent religions historically form an integral part of imperial enterprises. A volume based on the first meeting is currently under review at Cambridge University Press,,$^{32}$ and a few more are planned.

Apart from the database and the publications - completed and in progress - another important facet of the project has been the training of students. The project was implemented by an international team of emerging scholars. I established a young team, consisting at the beginning of the project of Israeli MA students together with international PhDs and post-docs. Although some of the students were very inexperienced at the beginning of our work, this allowed the core team to stay more or less throughout the duration of the project and work as a cohesive group that could learn together, share our experiences and provide feedback to one another. I placed a lot of emphasis on the linguistic skills - the team has been capable of working on sources in Arabic, Persian, Chinese, Russian, Mongolian, Latin, Japanese, Korean, Chaghatay Turkish and Tibetan in addition to the common European languages (French, German, Italian); and its members came not only from Israel, but also from China, Japan, Korea, the UK, the US, Germany and Italy. ${ }^{33}$ While some of the international

33 The project's core members, whose dissertations were described above are Or Amir, Matanya Gill, Ishayah Landa, Vered Shurany, and Qiao Yang. In addition, the members also included Na'ama Arom, Jonathan Brack, Wonhee Cho, Soyoung Choi, Francesca Fiaschetti, John Giebfried, Ofir Haim; Florence Hodous, Rachel Hoffman, Kaiqi Hua, Geoff Humble, Yoichi Isahaya, Amir Mazor, Undinne Ott, Qiu Yihao, Wuhaanch (Wh Hanqi), Nicholas Welmseley, Yu Yusen, Daniel Zakrzewski. 
students were rather challenging, others became key members of the project. Moreover, the international team enables us not only to work with multiple languages but also to combine a wide range of perspectives, skills, and sensitivities, and to study the Mongol Empire in a truly global way - as indeed it deserves to be studied.

The project conducted bi-weekly seminars in which members and guests presented their research, as well as various reading groups, led either by project members or the project's friends - and this is a good opportunity to thank Prof. Michael Lecker (Arabic sources); Prof. Yuri Pines (Chinese sources), as well as Daniel Zakrazevski (Persian sources), Dr. Wonhee Cho (Yuandianzhang), Dr. Yoichi Yisahaya (Ta'rikh-i Wassaf), Dr. Nick Walmsley (Chaghatay language) and Dr. Florence Houdos (Digital Humanities). The project enabled me to train and groom a group of talented students and post-docs, providing them with highly favorable conditions for pursuing their research including not only funding but also a supportive peer group, opportunities for presenting their research in local and international workshops and conferences, experience in organizing panels and workshops, and a chance to publish their own articles. I believe that quite a few of them will dominate the next generation of the scholars of the Mongol Empire.

Another major achievement of the project has been the globalization of the study of the Mongol Empire. The project convened two major international conferences, in June-July 2014 (Mobility and Transformations in Mongol Eurasia) and December 2017 (Migrations in Mongol Eurasia), as well as six smaller workshops, two together with the Humboldt Foundation (in addition to the comparative empires workshops described above): New Perspectives in Inner Asian Archaeology: Between Nomad and Sedentary Cultures (June 2013); Science and Technology Transfer in Pre-Modern Asia. (June 2014); Diplomacy in the Age of Mongol Globalisation (May 2016); Towards a Digital Eurasia (June 2016); Animals in Mongol Eurasia (February 2017) and Networks, Regions and Institutions: Meso-Historical Analysis (May 2017). ${ }^{34}$ All these gatherings included scholars from both East and West, both established scholars and emerging ones. The 2014 conference, already mentioned, also included a summer school "New Directions in the Study of the Mongol Empire", in which 10 leading scholars of the history of the Mongol Empire, all of them contributors to The Cambridge History of the Mongol Empire presented - in a session of 90-120 minutes each - the new and provocative aspects of his/her respective chapters, in front of their colleagues and a group of 25 carefully-chosen international students. Through these events - as well as through participation by the project's members in various other international gatherings - the project has created an international community of scholars of the Mongol Empire centered in Jerusalem. It fostered strong scholarly links between western (European, North American, Israeli) and eastern (from China, Korea, Japan and Mongolia) scholars of the Empire, encouraging East Asian researchers to present their scholarship in English. Simultaneously, members of the projects published not only in English but also in Chinese, Mongolian, Russian, Korean and Hebrew, ${ }^{35}$ thereby significantly contributing to the creation of international dialogue in the study of the Empire. This community and dialogue has continued even beyond the project's

34 For details, abstracts and organizers see mongol.huji.ac.il. The proceedings of some of these workshops are also in process.

35 See bibliography. 
formal ending: notably, the diplomacy workshop - a modest and focused event initiated by Francesca Fiaschetti and Marie Faveroux (Oxford), which enabled young scholars to introduce their research - encouraged its participants to convene follow-up workshops: I was the keynote speaker in the first such workshop, convened on May 2017 in Sofia, Bulgaria by Dr. Konstantin Golev, who participated in our diplomacy workshop, and devoted to Mongol Military history. Four project members and one former member also took part in this workshop that brought together mainly scholars from Eastern Europe. The May 2018 workshop on The Silk Roads in Mongol Eurasia was organized in Seged, Hungary by Dr. Marton Ver, another participant of the diplomacy workshop and a frequent visitor to Jerusalem. There were fewer project members in Seged, due to the proximity of the workshop to the Biennial Conference of Asian Studies in Israel which took place in Jerusalem in the same month, also featuring quite a few Mongol panels manned by international guests. ${ }^{36}$ However, another workshop is scheduled for spring 2019 in Vienna. These workshops are also one facet of the project's legacy.

In conclusion, the main impact of the project is that the study of the Mongol Empire now looks at the Mongols in their full Eurasian context and on their own terms, not only as a chapter in the annals of China, Iran, Russia or Inner Asia, but as a multi-faceted phenomenon in its own right - one that combined elements from various imperial traditions and made them its own - and which has had a broad and enduring impact on world history. In practical terms, this means that even scholars who work with only one corner (or language) of the empire now have to take into account the developments that took place in the other corners, while more students who are currently starting to explore the Mongols choose to study several languages (mainly Chinese and Persian) in order to pursue a holistic perspective.

Yielding publications that will be of interest to scholars dealing with multiple disciplines from regional studies (Chinese studies, Iranian studies; Middle Eastern studies; Inner Asian studies; European history and of course Mongolian studies) to world history, the study of migrations, cross-cultural contacts, comparative studies of empires, nomadism, conversion, transmission of knowledge; military history, the history of science, social history, cultural history, religious studies, as well as the digital humanities; training and grooming a considerable portion of the next generation of Mongol Empire scholars; and contributing significantly to the globalization of Mongolian studies worldwide, the project has left its mark on Mongolian studies and further afield. That said, however, despite its official ending on December 2017, the project is very much a work in progress. Its fully-fledged impact will become even clearer in the next few years when the several enterprises described above will be completed. Furthermore, the project's database will continue to yield fruits for years to come.

36 For details see asi18-huji.co.il/en. 


\section{Bibliography (references and project results ${ }^{37}$ )}

Academia Sinica's 24 histories database. Accessed on 6 November 2018: hanchi.ihp.sinica. edu.tw/ihpc/ttsweb?@o:o:1:hanji@@o.12200258094855054

Adey, Peter, Mobility (London and New York, 2009).

Aigle, Denise, The Mongol Empire between Myth and Reality: Studies in Anthropological History (Leiden, 2014).

Allsen, Thomas T., Commodity and Exchange in the Mongol Empire: A Cultural History of Islamic Textiles (Cambridge, 1997).

Allsen, Thomas T., Culture and Conquest in Mongol Eurasia (Cambridge, 2001).

Allsen, Thomas T., Population Movements in Mongol Eurasia, in: Reuven Amitai and Michal Biran (eds.) Nomads as Agents of Cultural Change (Honolulu, 2015) 119-151.

al-maktaba al-shamila. Accessed on 6 November 2018: islaamiclibrary.wordpress. com/2009/03/01/thecomprehensivelibrary/.

Amir, Or, Sufis and Mamluks: A Chapter in the Islamization of Palestine. Unpublished MA Thesis (The Hebrew University of Jerusalem, 2013).*

Amir, Or, The Religious Lives of Muslims in the Safed Area during the 13th-14th Centuries, According to a >New-Old Source, Cathedra 156 (2015) 39-70 [in Hebrew].*

Amir, Or, Niẓām al-Dīn Yahyā al-Ṭayyārī - An Artist in the Court of the Ilkhans and Mamluks, Asiatische Studien 71/4 (2017) 1075-1091.*

Amir, Or, Forming a New Local Elite: The 'Uthmani Family of Safed, in: Frédéric Bauden (ed.), The Mamluk Sultanate and Its Periphery (Leiden, forthcoming [2018]).*

Amitai, Reuven and Biran, Michal (eds.), Nomads as Agents of Cultural Change: The Mongols and Their Eurasian Predecessors (Honolulu, 2015).*

Amitai, Reuven and Biran, Michal, Arabic Sources for the Study of the Mongol Empire, in: Michal Biran and Kim Hodong (eds.), The Cambridge History of the Mongol Empire (Cambridge, forthcoming [2020]).*

Biran, Michal, The Mongol Transformation: From the Steppe to Eurasian Empire, Medieval Encounters 10/1-3 (2004) 338-361.

Biran, Michal, The Mongol Empire: The State of the Field, History Compass, 11/11 (2013) 1021-1033.*

Biran, Michal, Unearthing the Liao Dynasty's Relations with the Muslim World: Migrations, Diplomacy, Commerce and Mutual Perceptions, Journal of Song Yuan Studies 43 (2013) 221-251.*

Biran, Michal, Chahetai hanguo de waijiao yu qianshi guanli chutan 察合台汗国的外交 与 遣使惯例初探交, [Chaghadaid Diplomacy and Chancellery Practices: Some Preliminary Remarks] translated by Qiu Yihao, Xiyu yanjiu 2 (2014) 92-115 [Originally published in 2008].*

Biran, Michal, The Mongol Empire and the Inter-Civilizational Exchange, in: Benjamin Z. Kedar and Merry Wiesner-Hanks (eds.), The Cambridge History of the World: Vol. 5 (Cambridge, 2015) 534-558.*

Biran, Michal, Encounters among Enemies: Preliminary Remarks on Captives in Mongol Eurasia, Archivum Eurasia Medii Aevi 21 (2014-2015) 27-42.*

37 The project's publications are marked with *; I included only those mentioned in the text. 
Biran, Michal, Introduction: Nomadic Culture, in: Reuven Amitai and Michal Biran (eds.), Nomads as Agents of Cultural Change: The Mongols and Their Eurasian Predecessors (Honolulu, 2015) 1-10.*

Biran, Michal, The Mongols and Nomadic Identity: The Case of the Kitans of China, in: Reuven Amitai and Michal Biran (eds.), Nomads as Agents of Cultural Change: The Mongols and Their Eurasian Predecessors (Honolulu, 2015) 152-181.*

Biran, Michal, The Mental Maps of Mongol Central Asia As Seen from the Mamluk Sultanate, Journal of Asian History 49 (2015) 31-51.*

Biran, Michal, Qarakhanid Eastern Trade: Preliminary Notes on the Silk Roads in the 11th12th centuries, in: Jan Bemmann and Michael Schmauder (eds), The Complexity of Interaction along the Eurasian Steppe Zone in the first Millennium CE. Empires, Cities, Nomads and Farmers (Bonn Contributions to Asian Archaeology 7), (Bonn, 2015) 575-595.*

Biran, Michal, Mobility and Transformation: The Mongol Empire as a Turning Point in World History, Igeret, The Israel Academy of Sciences and Humanities 37 (2015)12-19 [in Hebrew].*

Biran, Michal, Music in the Conquest of Baghdad: Safi al-Din Urmawi and the Ilkhanid Circle of Musicians, in: Bruno De Nicola and Charles Melville (eds.), The Mongols' Middle East: Continuity and Transformations in Ilkhanid Iran (Leiden, 2016) 133-154.*

Biran, Michal, The Islamization of Hülegü: Imaginary Conversion in the Ilkhanate, Journal of the Royal Asiatic Society, third series, 26/1-2 (2016) 79-88.*

Biran, Michal, Chaghadaid-Golden Horde Relations (1260-1347), translated into Russian by Ishayahu Landa, in: Roman Hautala et al. (eds.), Zolotaia Orda v mirovoi istorii/The Golden Horde in World History (Kazan 2016) 363-367 [In Russian].*

Biran, Michal, The Fall and Rise of Ilkhanid Baghdad, translated into Mongolian by E. Enerelt and D. Bayarsaykhan, in: Dashdondog Bayarsaikhan and Christopher Atwood (eds.), New Approaches to Ilkhanid Research [Il-haadin sudlal shine handlaga] (Ulaanbaatar, 2016) 207-226 [in Mongolian].*

Biran, Michal, The Non-Han Dynasties, in: Michael Szonyi (ed.), The Blackwell Companion to Chinese History (Oxford, 2017) 129-143.*

Biran, Michal (ed.), In the Service of the Khans: Elites in Transition in Mongol Eurasia, Asiatische Studien 71/4 (2017)1051-1245.*

Biran, Michal, Violence and Non-Violent Means in the Mongol Conquest of Baghdad, in: Robert Gleave and István Kristó-Nagy (eds.), Violence in Islamic Thought from the Mongols to European Imperialism (Edinburgh 2018) 15-31.*

Biran, Michal, Scholarship and Science under the Qara Khitai (1124-1218), in: David O. Morgan and Sara Edwards (eds.), The Coming of the Mongols (London, 2018) 58-72.*

Biran, Michal, The Mamluks and Mongol Central Asia: Political, Economic and Cultural Aspects, in: Reuven Amitai and Stephan Connermann (eds.), The Mamluks in Global History (Bonn, forthcoming [2019]).*

Biran, Michal, Baghdad under Mongol Rule (565-736/1258-1335): Between History and Memory, in: Jens Scheiner and Isabel Toral-Niehoff (eds.), Handbook of Baghdad (Tübingen, forthcoming [2019]).*

Biran, Michal (ed.), Mobility and Transformation: Cultural Exchange in Mongol Eurasia, Journal of the Economic and Social History of the Orient 63/2-3 (2019) forthcoming.*

Biran, Michal, Libraries, Books and Transmission of Knowledge in Ilkhanid Baghdad, Journal of the Economic and Social History of the Orient 63/2-3 (2019) forthcoming.* 
Biran, Michal, The Mongol Imperial Space: From Universalism to Globalization, in: Yuri Pines, Michal Biran, Eva Canchik-Kirshbaum and Jörg Rüpke (eds.), Universality and Its Limits: Spatial Dimensions of Eurasian Empires (Cambridge, forthcoming [2019]).*

Brack, Jonathan Z., Mediating Sacred Kingship: Conversion and Sovereignty in Mongol Iran. Unpublished PhD dissertation (University of Michigan, 2016).

Brack, Jonathan Z., Theologies of Auspicious Kingship: the Islamization of Chinggisid Sacral Kingship in the Islamic World, Comparative Studies in Society and History 60/4 (2018) 1-29.*

Brack, Jonathan Z., A Mongol Mahdi in Medieval Anatolia: Reform, Rebellion, and Divine Right in the Post-Mongol Islamic World, Journal of the American Oriental Society, forthcoming (2019).*

Broadbridge, Anne F., Women and the Making of the Mongol Empire (Cambridge, 2018).

Cho, Wonhee, The Establishment and Significance of the Buddhist, Daoist, Christian and Manichaean Institutions around the Mongol Conquest of Southern China, Dongyang Sahak Yeonggu [Journal of Asian Historical Studies] 135 (2016) 211-244 [in Korean].*

Cho, Wonhee, Digital Humanities and Yuan Studies: An Introduction to the CBDB and its Potential, Chung'ang Asia Yon'gu [Central Asian Studies] 21/1 (2016) 117-133 [in Korean].*

Cho, Wonhee, New Insight on the Age of Ayurbarwarda (Ch. Renzong, r. 1311-1320) based on a Network Analysis of Officials, Chung'ang Asia Yon'gu [Central Asian Studies] 22/2 (2017) 73-96 [in Korean].*

Cho, Wonhee, An Examination of the Status of the Muslims in Yuan China: Based on the Analysis of Stone Inscriptions, Ewha Sahak Yeongu [A Bulletin of the Ewha Historical Institutions] 54 (2017) 213-245 [in Korean].*

Cho, Wonhee, From Military Leaders to Administrative Experts: The Biography of the »Treacherous Minister" Temüder and his Ancestors, Asiatische Studien 71/4 (2017) 12131230.*

Cho, Wonhee, Negotiated Privilege: The Tax Exemption Policies concerning Religion under the Mongol-Yuan Empire, Journal of the Economic and Social History of the Orient, forthcoming [2019].*

Choi, Soyoung, Kingship away from Kingdom: The Life of King Ch'ungsŏn (1275-1325), Asiatische Studien 71/4 (2017) 1093-1118.*

Cresswell, Tim, Mobilities I: Catching Up, Progress in Human Geography 35/4 (2011) 550558.

De Nicola, Bruno and Melville, Charles (eds.), The Mongols' Middle East: Continuity and Transformations in Ilkhanid Iran (Leiden, 2016).

Fiaschetti, Francesca and Schneider, Julia (eds.), Political Strategies of Identity Building in non-Han empires in China, Asiatische Forschungen 157 (Wiesbaden, 2014).

Fiaschetti, Francesca, Das Konzept des Auslandes in der Yuanzeit. Unpublished PhD dissertation (Ludwig-Maximilians-Universität, Munich, 2015).*

Fiaschetti, Francesca, The Borders of Rebellion: The Yuan Dynasty and the Rhetoric of Empire in: Francesca Fiaschetti and Julia Schneider (eds.), Political Strategies of Identity Building in non-Han empires in China, Asiatische Forschungen 157 (Wiesbaden, 2014) 127-146.

Fiaschetti, Francesca, Tradition, Innovation and the Construction of Qubilai's diplomacy, in: Ming Qing yanjiu 18 (2014) 65-96.* 
Fiaschetti, Francesca and Buell, Paul D., Est vs Ovest in termini mongoli: I Qan, le loro corti e il mondo esterno, in: Davor Antonucci (ed.), Ad Tartaros. La Mongolia tra Cina ed Occidente, Sulla Via del Catai 14 (2016) 41-63.*

Fiaschetti, Francesca, Mongol Imperialism in the Southeast - Uriyangqadai (1201-1272) and Aju (1127-1287), Asiatische Studien 71/4 (2017) 1119-1135.*

Fiaschetti, Francesca, The Six Duties: Yuan Diplomatic Interactions with Southeast Asia, in: Archivium Eurasiae Medii Aevii 23 (2017) 81-101.*

Fiaschetti, Francesca, Translating Heaven: Divination and Political Authority under the Yuan Dynasty, in: Patrick Manning, Abigail Owen (eds.), Knowledge in Translation: Global Patterns of Scientific Exchange, 100o-180o CE (Pittsburgh, 2018) 164-171.*

Gill, Matanya, Commerce in the Ilkhanid State (1260-1335) as Reflected by Ibn al-Fuwați's (d. 1323) Biographical Dictionary. Unpublished MA Thesis (The Hebrew University of Jerusalem, 2015).*

Golden, Peter B., Kovalev, Roman K., Martinez, A.P., Skaff, Jonathan and Zimonyi, A. (eds.), Festschrift for Thomas T. Allsen in Celebration of his 75th Birthday, Special Issue of Archivum Eurasia Medii Aevi 21 (2014-2015).

Grinberg, Moshe, The Foreign Policies of Janibeg, Khan of the Golden Horde (1342-57). Unpublished MA thesis (The Hebrew University of Jerusalem, 2017).*

Harzig, Christiane, Hoerder, Dirk and Gabaccia, Donna R., What is Migration History? (Cambridge, 2009).

Hodous, Florence, Clash or Compromise? Mongol and Muslim Law in the Ilkhanate (12581335), Proceedings of the European Conference of Iranian Studies 7 (2015) 187-196.*

Hodous, Florence, Faith and the Law: Death Penalty in the Ilkhanate, in: Bruno De Nicola and Charles Melville (eds.), The Mongols' Middle East: Continuity and Transformations in Ilkhanid Iran (Leiden, 2016) 106-129.*

Hodous, Florence, A Judge at the Crossroads of Cultures: Shi Tianlin, Asiatische Studien 71/4 (2017) $1137-1152 . *$

Hoerder, Dirk, Cultures in Contact: World Migrations in the Second Millennium (Durham, 2002).

Hollifield, James Frank and Brettell, Caroline, Migration Theory: Talking across Disciplines (3rd edition), (New York, 2015).

Humble, Geoffrey, >Han`Cultural Mobility under Mongol Rule: Biographies of the Jia 賈 Family, Asiatische Studien 71/4 (2017) 1153-1168.*

Isahaya, Yoichi, The Tärīkh-i Qitā in the Zīj-i İlkhānī: the Chinese Calendar in Persian, SCIAMVS: Sources and Commentaries in Exact Sciences 14 (2013) 149-258.*

Isahaya, Yoichi, Sino-Iranica in Pax Mongolica: The Elusive Participation of Syriac-Rite Christians in the Ilkhanid Translation Project, in: Rong Xianyang and Dang Baohai (eds.) Marco Polo and the Silk Road (10th-14th Centuries) (Beijing: forthcoming) 1-22.*

Isahaya, Yoichi and Endo, Mitsuaki, Persian Transcription of Yuan Chinese in the History of China of the Jämi' al-Tawärïkh (Ms. Istanbul, Topkapı Sarayı, Hazine 1654), The Economic Review 9 (2017) 123-161.*

Isahaya, Yoichi and Yang, Qiao, Islamicate Astral Sciences in Eastern Eurasia, in: Sonja Brentjes (ed.), Routledge Handbook on Science in the Islamicate World (London, forthcoming [2019]).*

JPP. Accessed on 6 November 2018: micro5.mscc.huji.ac.il:81/JPP/homepage/.

JPP-SPRING. Accessed on 6 November 2018: mongol.huji.ac.il/database. 
Jackson, Peter, The Mongols and the Islamic World from Conquest to Conversion (New Haven, CT, and London, 2017).

Landa, Ishayahu. Eurasian Migrations and Nomadic Identity: The Oyirad Tribe in the 13th14th Centuries. Unpublished MA Thesis (The Hebrew University of Jerusalem, 2014).*

Landa, Ishayahu, Imperial Sons-in-law on the Move: Oyirad and Qunqirad Dispersion in Mongol Eurasia, Archivum Eurasiae Medii Aevi 22 (2016) 161-198.*

Landa, Ishayahu, Oirats in the Ilkhanate and the Mamluk Sultanate in the Thirteenth to Fourteenth Centuries: Two Cases of Assimilation into the Muslim Environment, Mamluk Studies Review 19 (2016) 149-191.*

Landa, Ishayahu, Türaqai Güregen (d. 1296-7) and His Lineage: A History of a Cross-Asia Journey, Asiatische Studien 71/4 (2017) 1189-1212.*

Landa, Ishayahu, New Light on the Mongol Islamisation: The Case of Arghun Aqa, Journal of the Royal Asiatic Society 28/1 (2018) 77-100.*

Landa, Ishayahu, Reconsidering the Chinggisid Sons-in-law: Lessons from the United Empire, Chronica 18 (2018) forthcoming.*

Landa, Ishayahu, From Mongolia to Khwarazm: The Qonggirad Migrations in the Jochid Ulus (13c.-15c.), Revue des mondes musulmans et de la Méditerranée 143 (2018) forthcoming.*

Lucassen, Jan and Lucassen, Leo (eds.), Migration, Migration History, History: Old Paradigms and New Perspectives (3rd edition), (Bern, 2005).

Lucassen, Jan, Lucassen, Leo and Manning, Patrick, Migration History in World History: Multidisciplinary Approaches (Leiden, 2010).

May, Timothy and Jackson, Peter (eds.), The Mongols and Post-Mongol Asia: Studies in Honour of David O. Morgan, Special Issue of the Journal of the Royal Asiatic Society 26/1-2 (2016).

May, Timothy, The Mongol Empire (Edinburgh, 2018).

Mazor, Amir, The Rise and Fall of a Muslim Regiment: The Manșūriyya in the First Mamluk Sultanate, 678/1279-741/1341, Mamluk Studies 10 (Göttingen, 2015).*

Mazor, Amir, The Early Experience of the Mamluk in the First Period of the Mamluk Sultanate (1250-1382), in: Reuven Amitai and Christoph Cluse (eds.), Slavery and the Slave Trade in the Eastern Mediterranean (c. 1000-1500 CE) (Turnhout, 2017) 213-231.*

Mazor, Amir, The Topos of Predicting the Future in Early Mamluk Historiography, in: Stephan Conermann (ed.), Mamluk Historiography Revisited: Narratological Perspectives (Bonn, 2018) 103-120.*

Morgan, David O., Mongol Historiography since 1985: The Rise of Cultural History, in: Reuven Amitai and Michal Biran (eds.), Nomads as Agents of Cultural Change (Honolulu, 2015) 271-282.

McCausland, Shane, The Mongol Century: Visual Cultures of Yuan China (London, 2014).

Nathan, Ran, Getz, Wayne M., Revilla, Eloy, Holyoak, Marcel, Kadmon, Ronen, Saltz, David and Smouse, Peter E., A Movement Ecology Paradigm for Unifying Organismal Movement Research, Proceedings of the National Academy of Sciences 105/49 (2008) 19052-19059.

Pederson, Neil, Hessl, Amy E., Baatarbileg, Nachin, Anchukaitis, Kevin. J. and Di Cosmo, Nicola, Pluvials, Droughts, the Mongol Empire, and Modern Mongolia, Proceedings of the National Academy of Sciences 111/12 (2014) 4375-4379.

Pines, Yuri, Michal Biran, Eva Canchik-Kirshbaum and Jörg Rüpke (eds.), Universality and Its Limits: Spatial Dimensions of Eurasian Empires (Cambridge, forthcoming [2019]).

Pfeiffer, Judith, (ed.), Politics, Patronage, and the Transmission of Knowledge in 13th-15th Century Tabriz (Leiden, 2013). 
Qiu, Yihao 邱轶皓, 大德二年（1298）伊利汗国遣使元朝考一一法合鲁丁. 阿合马- 惕必的出 使及其背景, Dade ernian (1298) Yilihan guo jianshe Yuanchao kao- Faheluding Ahema Tibi de chushe ji qibeijing [The Mission of Fakhr al-Dīn Ahmad al-Ṭibì: a Resurvey of the Ilkhan's Envoy to Yuan Court in 1298], 中央研究院历史语言研究所集刊 Bulletin of Academia Sinica, 87 (2016) 67-124.*

Qiu, Yihao, The Background and Aftermath of Fakhr al-Dīn Tiibỉ's Voyage: a Resurvey on the Interaction between Ilkhanate and Yuan at Beginning of Fourteenth Century, trans. by E. Enerelt and D. Bayarsaikhan, in: Dashdondog Bayarsaikhan and Christopher Atwood (eds.), New Approaches to Ilkhanid Research [Il-haadin sudlal shine handlaga] (Ulaanbaatar, 2016) 373-408 [in Mongolian].*

Qiu, Yihao 邱轶皓, 萨迪诗歌中的蒙古帝国,Sadi shige zhong de Menggu diguo, [The Mongol Empire in Sa'di’s Poems], Wenhui bao 文汇报 (2016/4).

Qiu, Yihao 邱轶皓, 见诸波斯史料的一场元代宫廷政变 : 以〈瓦萨甫史〉 〈〈完者都史〉为中 心的考察 Jianzhu Bosi shiliao de yi zhang Yuandai gongting zhengbian: yi Wasafu shi, Wanzhidu shi wei zhongxin de kaocha [A Coup d'état in Yuan Court mentioned by Waș̣āf (sic)], in: Wang Yidan (ed), 伊朗学在中国论文集（第五辑）Yilanxue zai Zhongguo lunwen ji (di wu ji) Collection of Papers on Iranian Studies in China 5 (Beijing, 2018).*

Qiu, Yihao, Independent Ruler, Indefinable Role: Understanding the History of the Golden Horde from the Perspectives of the Yuan Dynasty, Revue des mondes musulmans et de la Méditerranée 143 (2018), forthcoming.*

Rachewiltz, Igor de, Chan, Hok-lam, Ch'i-ch'ing, Hsiao and Geier, Peter W., In the service of the Khan. Eminent personalities of the early Mongol-Yüan period (1200-1300) (Wiesbaden, 1993).

Shurany, Vered, Islam in Northwest China: The Life and Times of Prince Ananda (d. 1307). Unpublished MA Thesis (The Hebrew University of Jerusalem, 2015).*

Shurany, Vered, Prince Manggala - The Forgotten Prince of Anxi, Asiatische Studien 71/4 (2017) 1169-1188.*

Subrahmanyam, Sanjay, Connected Histories: Notes towards a Reconfiguration of Early Modern Eurasia, Modern Asian Studies 31/3 (1997) 735-762.

Urry, John, Sociology Beyond Societies: Mobilities for the Twenty-first Century (London, 2000).

Urry, John, Mobilities (London, 2007).

Yang, Qiao, Reading the Yuan Sky: Semu Astronomers and Cultural Exchange in Yuan China, Yuanshi Luncong, 14 (2014) 390-401 [in Chinese].*

Yang Qiao, Like Stars in the Sky: Astronomers in Mongol Eurasia. Unpublished MA thesis (The Hebrew University of Jerusalem, 2015).*

Yang, Qiao, From the West to the East, from the Sky to the Earth: Biography of Jamāl al-Dinn, Asiatische Studien 71/4 (2017) 1231-1245.*

Yang, Qiao, Like Stars in the Sky: Networks of Astronomers in Mongol Eurasia, Journal of the Economic and Social History of the Orient 63/2-3 (2019) forthcoming.*

Zakrzewski, Daniel, Malik Șadr al-Dīn Tabrīzì and the Establishment of Mongol Rule in Iran, Asiatische Studien, 71/4 (2017) 1059-1074.* 